\title{
Proprioceptive Training in Rehabilitation Therapy of Patients with Joint Stiffness after Boneblast around the Knee \\ M Liu, B Mi, S Fu
}

\begin{abstract}
Objective: To investigate effect of proprioceptive training in rehabilitation therapy of patients with joint stiffness after boneblast around knee.

Methods: Choose 42 patients with cases of stiff joints after boneblast around knee who receive rehabilitation treatment in our hospital during April 2013 -- September 2014, to be randomly divided into control group and observation group. The control group receives conventional rehabilitation treatment, while the observation group receives proprioception intensive training on the basis of the control group. Compare rehabilitation effect of 2 groups of patients.
\end{abstract}

Result: After receiving corresponding rehabilitation, the indicators of 2 groups of patients show significant improvement, but the degree of improvement in the observation group exceeds the control group. There is significant differences in comparison $(\mathrm{P}<0.05)$.

Conclusion: Proprioceptive training can promote recovery of joint stability, knee function, and balance function of patients with joint stiffness.

Keywords: Joint stiffness, proprioceptive training, rehabilitation therapy

From: Linyi People's Hospital, Linyi, 276000, China

Correspondence: Dr S Fu, Linyi People's Hospital, Linyi, 276000, China.

E-mail: fushubin_2016@126.com 


\section{INTRODUCTION}

Fractures around the knee can cause varying degrees of redness, swelling in soft tissue of knee. After treatment with boneblast around knee, prolonged fixation can result in knee dysfunction in patients, which exerts a serious impact on improving of life quality of patients (1). Therefore, in-depth study of effective rehabilitation interventions for stiff joints after boneblast around knee has important clinical implications (2). In this study, proprioceptive training for 21 patients with cases of joint stiffness after boneblast around knee achieved good rehabilitation effect, with report as follows.

\section{SUBJECTS AND METHODS}

This study selected 42 patients with cases of joint stiffness after boneblast around knee who received rehabilitation treatment in our hospital during April 2013 - September 2014 as research objects. The patients are equally divided in accordance with random number, with 21 respectively for the control group and the observation group. There is no significant difference $(\mathrm{P}>0.05)$ in comparison of general information of 2 groups of patients. Details are shown in Table 1. Figure 1 shows extension and flexion type of femoral condyle fracture.

\section{Measurements}

The control group received conventional rehabilitation treatment. Contents and measures of the therapy mainly consist of medicine fumigation, joint mobilization, traction of knee function, muscle strength training. The observation group received proprioceptive training on the basis of the control group. The specific training steps and contents are shown in Figure 1. 
The patients' proprioceptive training time lasts $6 \mathrm{~d}$.

\section{Criterion of treatment effect}

Eight weeks after patients received rehabilitation treatment, conduct Lysholm knee score scale (LKSS), score scale of artive range of motion (AROM), Berg balance scale (BBS). Evaluate effect of rehabilitation treatment based on scale results.

\section{Statistical analysis}

Adopt SPSS18.0 software for statistical analysis and processing of research data. Measurement data are indicated with standard deviation $(\mathrm{x}(-) \pm \mathrm{s})$, conduct t-test. Count data are indicated with $(\%)$, conduct $\mathrm{X}^{2}$ test. Significant differences in comparison of the two groups are indicated with $\mathrm{P}<0.05$.

\section{RESULTS}

Before receiving corresponding treatment, there is no significant difference $(\mathrm{P}>0.05)$ in LKSS, AROM, BBS scores of the two groups of patients. After receiving corresponding rehabilitation therapy, there is significant increase in LKSS, AROM, BBS scores of the two groups and there is significant difference $(\mathrm{P}<0.05)$ in comparison with the score before treatment. However, the degree of increase in the observation group obviously exceeds the control group. There is significance in comparison between the two groups $(\mathrm{P}<0.05)$, as shown in Table 2. 


\section{DISCUSSION}

After fractures around the knee, the primary injury, operation technique and postoperative fixation etc. can cause a certain degree of joint structural damage (3). The main reasons for knee stiffness after patients with fractures around the knee receive boneblast are local bleeding, redness, injured soft tissue, which causes adhesion and scar in scar tissue, and further leads to contracture, fibrosis of surrounding ligaments, muscle, joint capsule (4). Plus prolonged fixation, changes in tissues continuously accumulate, leading to gradual narrowing of joint mobility. Patella, tibia, femur and other bone traumas are likely to lead to occurrence of postoperative knee stiffness. Knee stiffness severely affects therapeutic effect of fractures and lowers prognosis (5). After joint stiffness occurs, patients not only suffer from tremendous pain, but also face greatly lowered articulation motor function, which leads to a series of dysfunction, lowers normal activity function of knee and exerts a serious impact on improving of life quality of patients. Therefore, strengthening prevention of postoperative knee stiffness after boneblast around knee and taking effective measures to promote maximal recovery of motor function of knee have become an important part in treatment and rehabilitation of fractures around the knee (6).

Conventional postoperative rehabilitation therapy focuses on training of joint range of motion, muscle strength, thereby promoting effective enhancement in joint flexibility, surrounding muscle strength, which is of great significance to improvement of knee function (7). However, without proprioceptive training in the rehabilitation process, recovery of knee control ability of patients isn't ideal, stability of the knee is reduced, which then decreases proprioception, and exerts a serious impact on knee rehabilitation. Guiding patients in 
proprioceptive training can not only promote good recovery of most proprioception, but also promote effective increase of joint range of motion, muscle contraction ability, thus contributing to better enhancement of knee function $(8,9)$.

In proprioceptive training, PNF technique effectively stimulates pacinian corpuscle, Golgi's organs and other knee proprioceptors mainly through various means such as skin contact, stretch reflex, extrusion and traction, while combining isotonic composition and other related technologies, thereby promoting continuous improvement of reflectivity and control ability of neuromuscular, enhancing stability of the knee and improving its control ability (10). By application of Thera-band cushion in balance training, instability can be gradually increased, knee's ability to adapt to changes can be improved, its dynamic stability can be enhanced and its balance function can be continually improved. Through lower limb training in Moto-med intelligent motion training system, knee movement and posture sense can be gradually increased through changes in velocity, direction and resistance (11).

In this study, patients in the observation group receive proprioceptive training on the basis of conventional rehabilitation therapy. Increase level of their LKSS, AROM, BBS scores is significantly better than that of the control group and there is significant difference in comparison.

\section{CONCLUSION}

In summary, during rehabilitation treatment of patients with joint stiffness caused by boneblast around the knee, except for conventional treatment, patients also receive 
proprioceptive training which can effectively expand patient's joint range of motion, improve knee joint stability, enhance its motion control capabilities, thereby enabling better recovery of affected knee and lower limb function, enhancing rehabilitation treatment effect, which is thus worthy of clinical application. 


\section{REFERENCES}

1. Wanxia W, Wuhua X, Wenquan L. Impact of Early Proprioceptive Training on Walking Ability of Patients after Total Knee Replacement. J Chin J Ortho Sur 2013; 15: $362-63$.

2. Zhilin W, Jingjin L. Observation of treatment effect of traditional chinese medicine fumigation method with conventional postoperative rehabilitation training for patients after boneblast around knee. J Trad Chin Med 2013; 11: 56-7.

3. Jichao Y, Xiaoxia L, Na L. Impact of alternating hot and cold therapy of traditional chinese medicine combined with rehabilitation on joint dysfunction after patellar boneblast. J Shaanxi Traditional Chinese Med 2015; 14: 369-70.

4. Cuizhen LI, Shiqin C, Mengmeng Z. Impact of Neuromuscular Joint Promotion (NJF) technique on rehabilitation of knee dysfunction. J Chin Disab Med 2013; 2: $167-8$.

5. Liangce S, Qiuhong Y, Yuling W. Application of isokinetic training in rehabilitation of knee stiffness after femoral fracture braking. J Chin J Rehabi Theory and Practice 2012; 6: 282-3.

6. Sihai L, Zhigang C, Kemin L. Rehabilitation therapy of post-traumatic knee stiffness. J Chin Clinicians 2012; 11: 658-9.

7. Li W, Rong B, Yi Z. Monitored rehab systems application of comprehensive training of lower limb in function rehabilitation of knee joint. J Chin Disab Med 2013; 13: $211-2$.

8. Xiaodong L. Clinical study of high-frequency ultrasound in knee stiffness diagnosis 
and treatment evaluation. J Chin J Ortho Surg 2013; 18: 468-9.

9. $\mathrm{Xu} \mathrm{L}$, Xianfeng G. Rehabilitation therapy after ligament reconstruction of inner patellar femoral after patellar dislocation. J Chin J Rehab Med 2013; 6: 105-6.

10. Shiqin C. Primary investigation into treatment of elbow joint dysfunction with joint mobilization (MWP) technique combined with PNF. J Chin Disab Med 2012; 8: $98-9$.

11. Xin L, Lei W, Yuguo H. Impact of early intervention of rehabilitation on ankle function after pilon boneblast. J Chin J Rehab Med 2014; 16: 352-3. 
Table 1: Comparison of general information of 2 groups of patients

\begin{tabular}{llllllll}
\hline Group & $\mathbf{n}$ & $\begin{array}{l}\text { Average } \\
\text { age(year) }\end{array}$ & \multicolumn{2}{l}{$\begin{array}{l}\text { Gender } \\
\text { (cases) }\end{array}$} & \multicolumn{2}{l}{ Fracture type (case) } & \\
& & Fem & Mal & $\begin{array}{l}\text { Femoral } \\
\text { e }\end{array}$ & $\begin{array}{l}\text { Femoral } \\
\text { fracture }\end{array}$ & $\begin{array}{l}\text { Froximal } \\
\text { shaft } \\
\text { fracture }\end{array}$ & $\begin{array}{l}\text { Procture } \\
\text { tibial } \\
\text { fracture }\end{array}$ \\
\hline $\begin{array}{l}\text { Observ } \\
\text { ation } \\
\text { group }\end{array}$ & 2 & $36.5 \pm 2.1$ & 6 & 15 & 13 & 3 & 5 \\
$\begin{array}{l}\text { Contro } \\
\text { lgroup }\end{array}$ & 2 & $36.8 \pm 1.8$ & 7 & 14 & 10 & 5 & 6 \\
\hline
\end{tabular}

Table 2: Changes of the indicators of the 2 groups of patients

\begin{tabular}{|c|c|c|c|c|c|c|}
\hline \multirow[t]{2}{*}{ Group } & \multicolumn{2}{|c|}{ LKSS (score) } & \multicolumn{2}{|l|}{$\operatorname{AROM}\left(^{\circ}\right)$} & \multicolumn{2}{|c|}{ BBS (score) } \\
\hline & $\begin{array}{l}\text { Before } \\
\text { treatment }\end{array}$ & $\begin{array}{l}\text { After } \\
\text { treatment }\end{array}$ & $\begin{array}{l}\text { Before } \\
\text { treatment }\end{array}$ & $\begin{array}{l}\text { After } \\
\text { treatment }\end{array}$ & $\begin{array}{l}\text { Before } \\
\text { treatment }\end{array}$ & $\begin{array}{l}\text { After } \\
\text { treatment }\end{array}$ \\
\hline $\begin{array}{l}\text { Observ } \\
\text { ation } \\
\text { group }\end{array}$ & $35.5 \pm 8.7$ & $93.5 \pm 5.2^{* \#}$ & $56.8 \pm 8.6$ & $\begin{array}{l}119.5 \pm 5.3^{*} \\
\#\end{array}$ & $30.4 \pm 4.5$ & $53.6 \pm 1.7^{* \#}$ \\
\hline $\begin{array}{l}\text { Contro } \\
1 \text { group }\end{array}$ & $36.5 \pm 5.9$ & $78.3 \pm 5.8^{*}$ & $57.5 \pm 6.9$ & $100.2 \pm 8.4$ & $30.7 \pm 5.7$ & $45.1 \pm 2.7^{*}$ \\
\hline
\end{tabular}



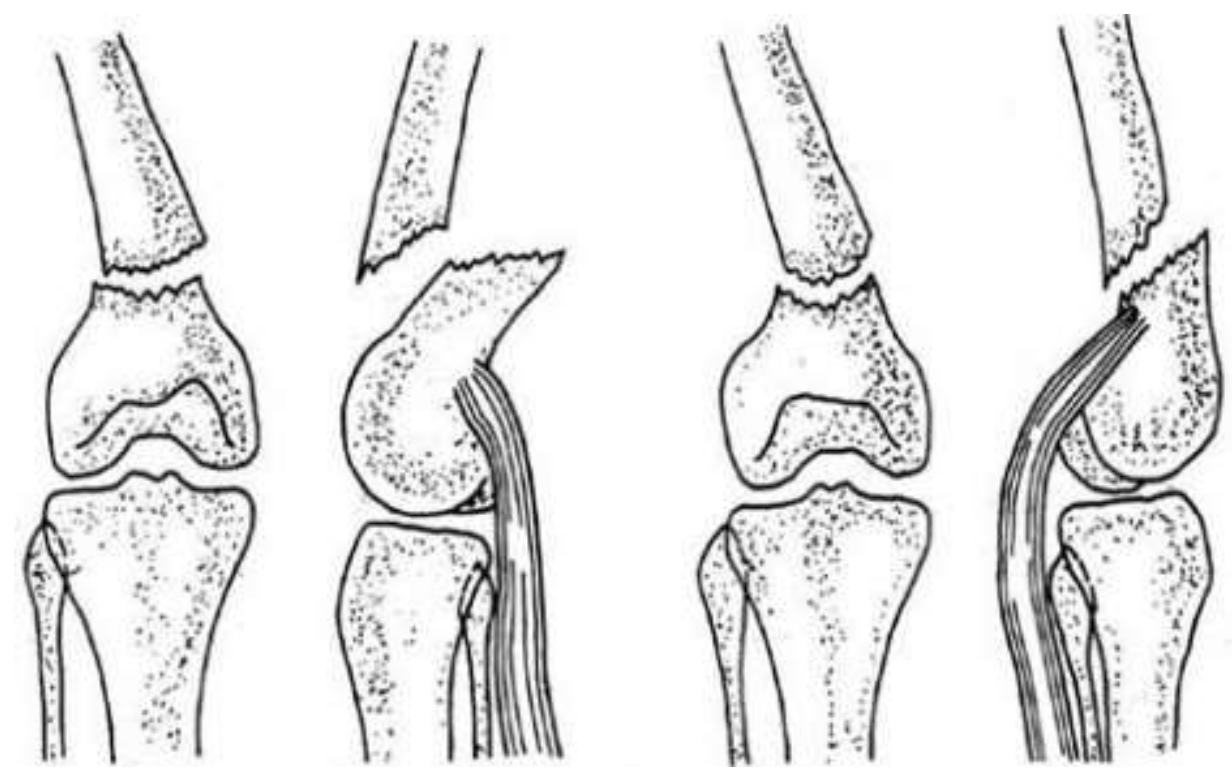

Fig. 1: Extension and flexion type of femoral condyle fracture

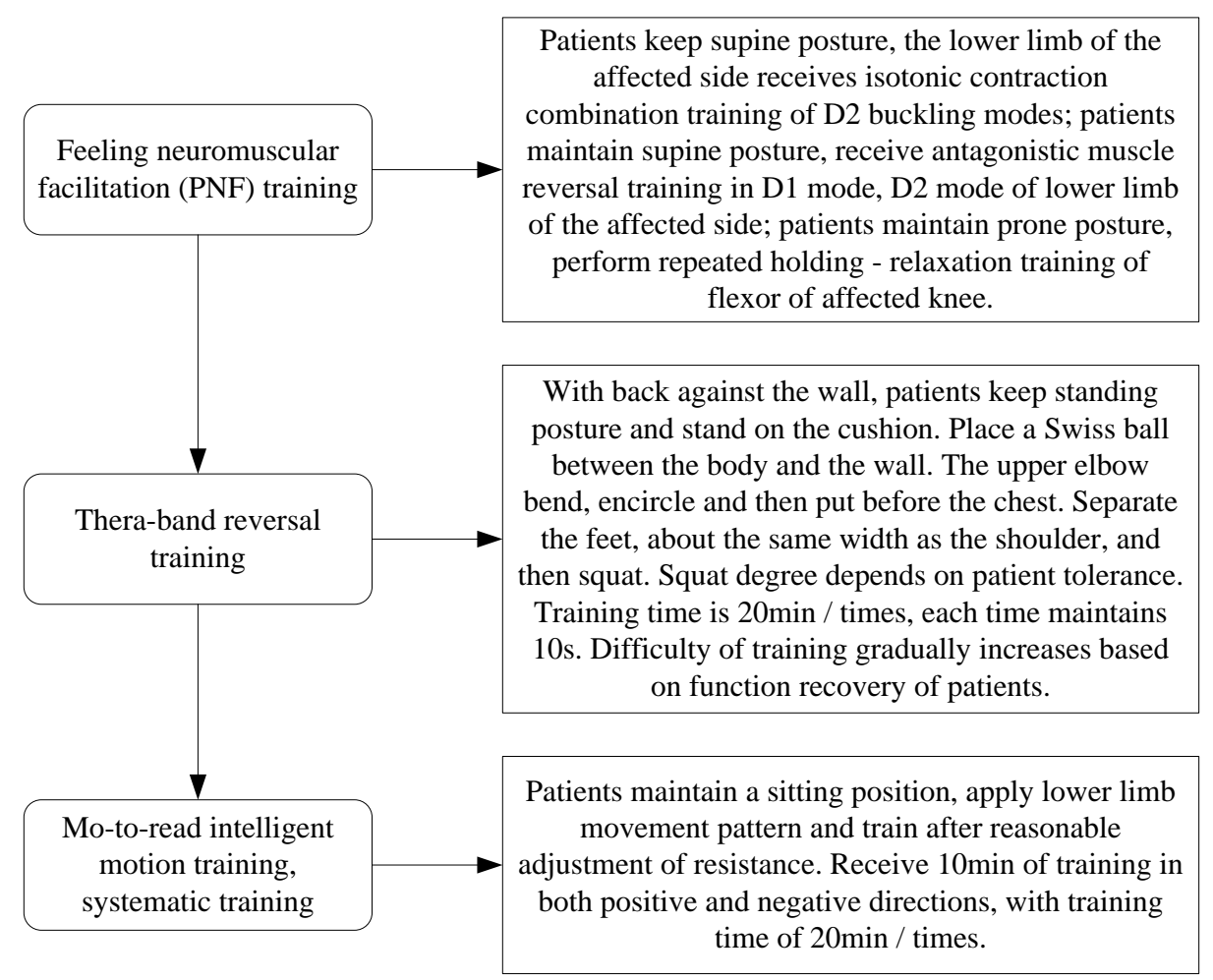

Fig. 2: Proprioceptive training procedures and contents. 